\title{
The fashion-conscious behaviours of mature female consumers
}

\author{
Jinhee Nam, Reagan Hamlin, Hae Jin Gam, Ji Hye Kang, Jiyoung Kim, Pimpawan Kumphai, Cathy Starr \\ and Lynne Richards
}

Department of Design, Housing and Merchandising, Oklahoma State University, Stillwater, OK, USA

\begin{abstract}
Keywords
Apparel, consumer behaviour, elderly, fashion consciousness, mature, shopping behaviour.

\author{
Correspondence \\ Lynne Richards, College of Human \\ Environmental Sciences, Design, Housing and \\ Merchandising, 431 Human Environmental \\ Sciences, Stillwater, OK 74078-6142, USA. \\ E-mail: lynne.richards@okstate.edu
}

doi: 10.1111/j.1470-6431.2006.00497.x

\begin{abstract}
Under-appreciation of mature consumers as a numerous and comparatively wealthy market segment has resulted in not only lost revenues for business, but also lost consumption and service opportunities for the elderly. In response to expressed needs for more research into actual and desired consumption by older consumers, this study examined the apparel and shopping preferences of mature women in America. Independent living residents were surveyed concerning fashion consciousness, fashion information sources and shopping behaviours. Young and mature consumers' reactions to female apparel ensembles were compared. Mature subjects purchased apparel for pleasure or need, but less for conformity. Decisions were influenced more by fit and comfort than by fashion, despite suggestions that dressing stylishly was important. New fashions were encountered via catalogue illustrations, social gatherings and window displays. Subjects high in fashion consciousness had greater financial and social involvement with fashion, greater chronological-to-cognitive age differences and larger clothing budgets. Young and mature consumers' responses to apparel illustrations differed significantly. As the mature market expands, attention to age-divergent definitions of fashion (such as those based upon admiration of comfort) will determine the success of apparel businesses. Assessment of cognitive age will facilitate identification of those mature consumers most predisposed toward fashion consumption.
\end{abstract}

In the year 2000, American households in the 55-to-64 market segment had a median net worth 15 times greater than that reported for those in the under-35 age group (i.e. $\$ 112048$ vs. \$7240) (Anonymous, 2004). By the year 2020, persons aged 55 years and over will comprise $33 \%$ of the US population and will continue to control household assets far greater than younger consumers (Carrigan and Szmigin, 1999). Yet, despite the growing number and obvious wealth of older consumers, they remain one of the most under-appreciated consumer segments. Apparel companies have largely neglected the elderly in their feverish pursuit of the youth market (Solomon and Rabolt, 2004).

This lack of attention to the lucrative older market has been attributed to a number of factors. Thomas and Wolfe (1995), for example, suggested that focus upon the product needs and preferences of young (rather than old) consumers is directly due to the fact that most persons employed in product promotion are themselves young. Corlett (1998), on the other hand, promulgated that lack of attention to the mature market stems from marketers' comfort with long-standing promotional strategies developed during earlier decades when young consumers were in the majority. Lack of interest in older consumers also has been attributed to the negative stereotypes associated with ageing, and businesspersons' fears that their products will become associated with senility, disability or unattractiveness (Lee, 1997; Long, 1998; Tunaley et al., 1999). Finally, some marketers avoid the mature market, seeing it as a dead-end sales opportunity. As one advertising executive explained, courting mature consumers offers little return on investment 'because they [will] . . . all die soon' (Miller, 1993).

In contrast with the above negativism toward the mature market (usually defined as those persons aged 55 years and over), research has revealed that older consumers are wealthy, innovative, and have a desire to actively participate in mainstream consumption (Szmigin and Carrigan, 2001). According to Solomon and Rabolt (2004), today's elderly are active, interested in appearance and what life has to offer, and enthusiastic consumers with the means and willingness to buy many goods and services. In fact, older consumers often are the best target for luxury products (Gardyn, 2002). Inattention to this consumer segment has resulted in lost revenues for business, as well as lost consumption and service opportunities for the elderly.

It is true that few people aspire to be old. In fact, research studies have revealed that most people feel younger than their actual age (Barak and Schiffman, 1981; Barak, 1987; Stephens, 1991). Greco (1986) suggested that some older persons cognitively view themselves as much as 10-15 years younger than their chronological age. Cognitively young elders tend to be more 
willing to try new product brands, are more likely to seek product information, are more self-confident in their decision making, and are more likely to be opinion leaders and brand switchers (Barak and Gould, 1985; Sherman et al., 1988; Silvers, 1997). The cognitively young also exhibit greater fashion interest, and therefore may be more active consumers of apparel fashion products (Wilkes, 1992; Schiffman and Kanuk, 1994). Wilkes (1992) observed that the levels of fashion interest manifested by older women suggested that cognitively 'young' older women do continue to be concerned about their appearance.

\section{Literature review}

Fashion consciousness refers to a person's degree of involvement with the styles or fashion of clothing. An individual does not have to be either a fashion opinion leader or a fashion innovator to be considered fashion conscious. Rather, fashion consciousness is characterized by an interest in clothing and fashion, and in one's appearance (Summers, 1970; Jonathan and Mills, 1982).

Walsh et al. (2001) found that fashion consciousness among German consumers was related to a desire for up-to-date styles, frequent changes in one's wardrobe and pleasurable shopping experiences. Obviously, fashion consciousness is a convenient consumer attribute for apparel marketers, in that this pre-existing interest in clothing can increase consumer receptivity to apparel product promotions (Richards and Sturman, 1977; Kaiser and Chandler, 1984). Lumpkin (1985) found that a high proportion of active mature consumers were relatively heavy spenders on clothing, and therefore concluded that fashion-conscious segments do exist among older apparel shoppers. Similarly, Barak and Stern (1985) noted that fashion-conscious women often feel younger than their chronological age. However, no relationship was found between age perception and fashion consciousness in Chowdhary's (1988) study. She also observed that although $80 \%$ of persons aged 65-91 said that they preferred to wear 'stylish clothing', only $25 \%$ actually chose apparel that was currently fashionable. The remaining $75 \%$ selected classic styles more fashionable in previous decades, suggesting that perceptions of what is fashionable may vary with age.

Previous studies have also investigated the relationship between the fashion consciousness of mature consumers and the fashion information sources used by members of that market segment. Kaiser and Chandler (1985), for example, observed that older people implicitly use television for processing appearance and fashion-related information. Greco and Paksoy (1989) similarly found that fashion-conscious shoppers rely more on mass media information sources than do non-fashion-conscious segments. Surprisingly, the mature market represents the second fastest growing population segment engaged in Internet use (exceeded only by teens), with women primarily responsible for this surge in activity. Therefore, the Internet may also become a viable source of fashion information (Ross, 2000).

Research has suggested that like all other age cohorts, the mature market is not homogeneous (Carrigan, 1998). Schiffman and Sherman (1991) identified a mature market sub-segment which they labelled the new-age elderly. Mathur et al. (1998) observed that these new-age elderly (in comparison with other mature consumers) have different value orientations, younger cognitive ages and greater self-confidence, and are more receptive to change, including willingness to try new products and experiences. Due to these differences, the researchers recommended approaching the mature market with value-based marketing strategies, rather than age-based ones.

Szmigin and Carrigan (2001) concluded that '... what is now needed is more research into actual and desired consumption by the older consumer. Older women in particular have been largely neglected. We need to understand what the older consumers themselves want in terms of lifestyle, appearance, products and media' (p. 30). In response to this call for research, the current investigation was designed to assess the apparel fashion perceptions, fashion consciousness, fashion information source utilization and shopping practices of mature American women (Part I), as well as to compare opinions about product fashion held by younger and older female consumers (Part II).

\section{Method}

\section{Sampling method: Part I}

Most previous studies of the mature market have focused on populations aged 55 years and over or 65 and over. The targeted population for this investigation was designated as women of 65 years or older, the age commonly associated with retirement within the US. A sample population of 55 years and over would introduce the potential intervening variable of two divergent lifestyles, and therefore a less homogeneous sample.

In Part I of the project, a convenience sample of mature women was obtained from the resident populations of three independent living facilities located in the Midwestern United States. Independent living facilities were chosen due to the interactive community setting and the fact that residents were able to care for themselves and make autonomous consumer decisions. Before visiting each of the centres, a facility supervisor was contacted and a time was arranged for group administration of the survey instrument. Before administering the questionnaire, the research was approved by the Institutional Review Board at Oklahoma State University, and all subjects signed a consent form. After the respondents had completed the survey, they were rewarded with an appreciation presentation featuring information about current trends in apparel and interiors. For analysis, the resulting sample was subdivided into younger $(65-75$ years, $n=8)$ and older retirees (i.e. the elderly, 76 or more years, $n=52$ ) for the purpose of analysis.

\section{Sampling method: Part II}

Part II of the procedure, which compared perceptions of garment fashion held by mature and young adult female consumers, consisted of two additional convenience samples. Opinions regarding fashion were collected from members of a local bridge club, whose ages ranged from 70 to 85 , thus representing both younger and older retirees. Younger women's opinions were collected from university students whose ages ranged from 18 to 21 years.

\section{Instrumentation}

Instrumentation for Part I of the project consisted of a selfcompletion survey instrument, assessing older women's fashion consciousness, use of fashion information sources and shopping 
behaviours. This instrument was administered to female residents of the three independent living facilities. Concerning fashion consciousness, the subjects responded to five 5-point Likert questions extracted from Lumpkin and Darden's (1982) six-question set, for which an alpha reliability coefficient of 0.71 was reported.

In additional, four questions were added to the Part I instrument to investigate apparel preferences and behaviours of older women, such as an item that assessed preferences for trousers vs. dresses. This survey instrument also included additional questions concerning the respondents use of fashion information sources, their shopping behaviours and selected demographic variables (including cognitive age).

To compare the fashion perceptions of mature female consumers with younger ones, the goal of Part II of the project, 18 pictures of women's trouser ensembles were randomly selected from a variety of magazines. These pictures were shown to the aforementioned bridge club members and university students. Each individual rated each ensemble as having high, medium or low fashion, using a 3-point scale with 1 indicating high fashion.

\section{Data analysis}

In Part I, responses were analysed using frequency statistics and independent sample $t$-tests. The latter statistical method was used to assess differences between mature persons high and low in fashion consciousness, and differences between younger (age 6575 years) and older retirees (76 or more years). In Part II, an independent sample $t$-test was used to assess differences between mature and young consumers in regards to perceptions.

\section{Results}

\section{Part I}

\section{Demographic profile of independent living residents}

In total, 63 self-completion surveys were collected and used for analysis, although a few subjects did not respond to all items. Among the 63 respondents, 60 reported ages from 66 to 101 years, with a mean chronological age of 82.43 . Young retirees (6575 years) constituted $86.67 \%$ of the sample, while older retirees (76 and above) represented $13.33 \%$.

Only 34 persons answered the item pertaining to cognitive age. Thirty of these subjects (94\%) indicated lower felt ages, averaging a 19.24 difference from their chronological ages. Only two subjects gave their cognitive ages as being higher than their chronological ages (13 years and 1 year respectively). One final subject indicated that her cognitive and chronological ages were identical. Regarding marital status, $62.3 \%(n=38$ out of 61$)$ identified themselves as being widowed; $19.7 \%$ were married; $11.5 \%$ were single and $6.6 \%$ were divorced. Reports of annual income ranged from $\$ 2000$ (or less) to $\$ 50000$ (or more).

Funds annually available for personal apparel purchasing ranged from zero to $\$ 5000$. When queried about the frequency of purchasing fashion apparel, a majority of the subjects $(65.1 \%)$ stated that they bought new fashion items once or twice each year. Only $6.3 \%$ indicated that they purchased apparel fashion products more than six times each year.

In a separate survey item, respondents were asked to rank the importance of four apparel attributes to their clothing purchase decisions: fashion, comfort, quality and fit. Only 26 subjects responded to this item, resulting in the highest mean score (i.e. greatest importance) being assigned to fit (2.85 points out of 4), followed by comfort (2.77), quality (2.69) and fashion (2.23).

\section{Fashion consciousness}

Five questions on the survey instrument assessed fashion consciousness, or interest in apparel styles and fashion. The responses and analyses of these results are reported in Table 1. In general, respondents gave positive ratings concerning ownership of fashionable apparel and the importance of dressing 'smartly' or in style. However, the subjects were less positive concerning the value of owning apparel in the latest style, and the relative importance of fashion vs. comfort, paralleling the ranking of clothing attributes given above.

Other survey items requested further information about fashion preferences and actions (Table 2). The responses suggest that, in

Table 1 Mean responses to individual fashion-conscious items

\begin{tabular}{|c|c|c|c|c|c|}
\hline Question & $n$ & Minimum & Maximum & Mean $^{\mathrm{a}}$ & SD \\
\hline I usually have one or more outfits that are of the latest style. & 57 & 1 & 5 & 3.78 & 1.02 \\
\hline When I must choose between the two, I dress for fashion, not for comfort. & 61 & 1 & 5 & 2.90 & 1.22 \\
\hline An important part of my life and activities is dressing smartly. & 60 & 1 & 5 & 3.77 & 1.03 \\
\hline It is important to me that my clothes be of the latest style. & 61 & 1 & 5 & 2.80 & 1.26 \\
\hline A person should try to dress in style. & 58 & 1 & 5 & 3.67 & 0.96 \\
\hline
\end{tabular}

Table 2 Mean responses to fashion behaviour and preferences items

\begin{tabular}{|c|c|c|c|c|c|}
\hline Question & $n$ & Minimum & Maximum & Mean $^{a}$ & $\mathrm{SD}$ \\
\hline In general do you like to talk about fashion/clothing with your friends? & 61 & 1 & 5 & 3.30 & 1.30 \\
\hline During the past six months, have you told anyone about some fashion/clothing information? & 58 & 1 & 5 & 3.40 & 1.35 \\
\hline My friends think of me as a knowledgeable source of information about fashion trends. & 61 & 1 & 5 & 2.79 & 1.29 \\
\hline When given the choice, I always choose to wear slacks over dress. & 61 & 1 & 5 & 3.74 & 1.44 \\
\hline
\end{tabular}

a $5=$ Agree; 1 = Disagree. 
general, the subjects did discuss fashion with friends, and many perceived themselves as being at least somewhat knowledgeable about fashion trends. In addition, the responses indicated a tendency to prefer trouser ensembles over dresses.

\section{Fashion information sources}

Subjects were asked to identify those information sources by which they first become aware of new clothing styles. The results indicated that older female consumers most frequently stay current with new fashion trends by observing them in catalogues, at social gatherings, in store displays, in fashion magazines or through friends (Table 3).

\section{The why and where of purchasing}

Regarding motivations for clothing purchases, the participants were asked to select the two most typical reasons for why they purchase fashionable apparel (Table 4). The hedonic need for 'personal enjoyment' appeared to be important to these mature consumers, with regards to clothing purchases, as were the more utilitarian needs for apparel appropriate to season or event. A need for conformity with peers, on the other hand, was not perceived to be as great an influence.

When asked where they most frequently acquired fashionable apparel, the respondents revealed decided preferences for department and specialty stores. Acquiring apparel from catalogues, in this older market, was more prevalent than purchasing apparel in discount stores (Table 5). The Internet and home sewing represented the apparel sources least availed by members of this sample.

Table 3 Fashion information sources used by mature women

\begin{tabular}{lll}
\hline Information source & $\begin{array}{l}\text { Persons } \\
\text { responding }\end{array}$ & $\begin{array}{l}\text { Percentage } \\
(n=60)\end{array}$ \\
\hline Catalogues & 35 & 58.33 \\
Observing clothing at social gatherings, & 32 & 53.33 \\
$\quad$ public places & & \\
Window or store displays & 31 & 51.67 \\
Friends & 23 & 38.33 \\
Fashion magazines & 23 & 38.33 \\
Fashion shows & 13 & 21.67 \\
Salespersons & 13 & 21.67 \\
Asking family members for their opinions & 13 & 21.67 \\
Discussions with other women & 10 & 16.67 \\
Internet & 4 & 6.67 \\
Fashion counsellors & 2 & 3.33 \\
Pattern books & 2 & 3.33 \\
\hline
\end{tabular}

Table 4 Mature women's motivation for clothing purchases

\begin{tabular}{lll}
\hline Motivation & Persons responding & Percentage $(n=62)$ \\
\hline Personal enjoyment & 32 & 51.61 \\
Special occasions & 31 & 50.00 \\
Seasonal changes & 30 & 48.39 \\
Fit in with my peers & 19 & 30.65 \\
\hline
\end{tabular}

\section{Fashion consciousness in relation to other variables}

For each subject, responses to the five fashion-conscious items (questions presented in Table 1) were averaged, and the respondents then were divided into two groups: higher vs. lower fashion consciousness. Persons with mean response scores at 3.0 or higher were categorized as having higher fashion consciousness $(n=41)$, while respondents having mean scores lower than 3.0 were considered as having lower fashion consciousness $(n=12)$. A $t$-test was used to compare scores of the five fashion-conscious questions between the higher and the lower fashion-conscious group. The results revealed a significant difference on all of the five fashionconscious items between the two groups $(P<0.01)$.

The higher vs. lower fashion-conscious groups then were compared using independent sample $t$-tests, to determine the presence or absence of significant differences with regards to other previously mentioned variables (Table 6). Subjects with higher fashion consciousness were significantly different from those with lower fashion consciousness in regards to talking about fashion with friends $(P<0.01)$ and perceiving themselves to be knowledgeable about fashion trends $(P<0.05)$. Respondents with higher fashion consciousness also had higher chronological ages, lower cognitive ages, larger chronological-cognitive age gaps, higher clothing budgets, more social involvement with fashion, and greater preference for trousers than persons with lower fashion consciousness, although these latter differences were not statistically significant.

The higher and lower fashion-conscious groups were also compared in regards to the importance assigned to the four clothing selection attributes: fashion, comfort, quality and fit (due to some subjects not responding to both the fashion consciousness and the clothing attribute questions, $n=23$, with only four subjects representing lower fashion consciousness). Differences between these two groups, in regards to the ranking of clothing attributes, were minimal and not significantly different (Table 7).

\section{Younger and older retirees comparison with other variables}

Additionally, respondents were divided into two subgroups (young retirees aged 65-75, and older retirees aged 76 or more), and the responses to all questionnaire items were compared. The results indicated no significant differences between these two groups, with the exception of one item - the frequency of apparel shopping. Younger retirees appeared to shop significantly more often than the older ones in this study. More specifically, younger retirees $(n=8)$ most frequently indicated shopping for apparel 1-2 times $(n=3)$ or $3-5$ times $(n=3)$ per year, while older ones

Table 5 Mature women's preferred sources of fashion apparel

\begin{tabular}{lll}
\hline Where do you purchase clothing? & $\begin{array}{l}\text { Persons } \\
\text { responding }\end{array}$ & $\begin{array}{l}\text { Percentage } \\
(n=61)\end{array}$ \\
\hline Specialty stores & 40 & 65.57 \\
Department stores & 38 & 62.30 \\
Catalogue shopping & 27 & 44.26 \\
Discount stores & 20 & 32.79 \\
Taylor-made & 10 & 16.39 \\
Internet & 6 & 9.84 \\
Home sewn & 4 & 6.56 \\
\hline
\end{tabular}


Table 6 T-test comparisons of higher vs. lower fashion-conscious consumers

\begin{tabular}{|c|c|c|c|c|c|c|}
\hline Variable & Group $^{a}$ & $n^{\mathrm{b}}$ & Mean & SD & $t$ & $P$ \\
\hline \multirow[t]{2}{*}{ Age } & 1 & 40 & 82.78 & 7.51 & 0.62 & 0.54 \\
\hline & 2 & 11 & 81.18 & 7.43 & & \\
\hline \multirow[t]{2}{*}{ Cognitive age } & 1 & 22 & 62.41 & 15.40 & 0.94 & 0.36 \\
\hline & 2 & 6 & 68.67 & 9.20 & & \\
\hline \multirow[t]{2}{*}{ Difference of cognitive age from chronological age } & 1 & 22 & 18.73 & 12.15 & 1.67 & 0.11 \\
\hline & 2 & 6 & 9.17 & 13.68 & & \\
\hline \multirow[t]{2}{*}{ Budget for wardrobe } & 1 & 15 & 1480.00 & 1513.37 & 1.01 & 0.33 \\
\hline & 2 & 7 & 864.29 & 784.60 & & \\
\hline \multirow[t]{2}{*}{ In general do you like to talk about fashion/clothing with your friends? ${ }^{c}$} & 1 & 41 & 3.59 & 1.16 & 4.71 & $0.00 * *$ \\
\hline & 2 & 12 & 1.83 & 1.03 & & \\
\hline \multirow[t]{2}{*}{ During the past six months, have you told anyone about some fashion/clothing information?c } & 1 & 39 & 3.56 & 1.33 & 1.08 & 0.28 \\
\hline & 2 & 12 & 3.08 & 1.38 & & \\
\hline \multirow[t]{2}{*}{ My friends think of me as a knowledgeable source of information about fashion trends. ${ }^{c}$} & 1 & 41 & 2.98 & 1.31 & 2.17 & $0.04^{*}$ \\
\hline & 2 & 12 & 2.08 & 0.99 & & \\
\hline \multirow[t]{2}{*}{ When given the choice, I always choose to wear slacks over dress. ${ }^{c}$} & 1 & 41 & 4.05 & 1.24 & 1.72 & 1.06 \\
\hline & 2 & 12 & 3.16 & 1.64 & & \\
\hline
\end{tabular}

${ }^{a}$ Group 1: higher fashion-conscious group ( $\left.\geq 3.0\right)$; Group 2: lower fashion-conscious group (<3.0).

${ }^{b} V a r i a b l e ~ N s$ due to some subjects not responding to all items.

${ }^{\circ} 5=$ Agree; 1 = Disagree.

${ }^{*} P=0.05 ;{ }^{*} P=0.01$.

Table 7 Importance of clothing attributes to higher and lower fashionconscious consumers

\begin{tabular}{lllllll}
\hline $\begin{array}{l}\text { Higher fashion-conscious group } \\
(n=19)\end{array}$ & & \multicolumn{2}{l}{$\begin{array}{l}\text { Lower fashion-conscious group } \\
(n=4)\end{array}$} \\
\cline { 1 - 1 } Attribute & Mean & SD & & Attribute & Mean & SD \\
\hline Fit & 2.89 & 1.05 & & Comfort & 3.00 & 1.41 \\
Comfort & 2.74 & 1.24 & & Fashion & 2.50 & 1.73 \\
Quality & 2.63 & 1.01 & & Quality & 2.25 & 0.95 \\
Fashion & 2.26 & 1.14 & & Fit & 2.25 & 0.50 \\
\hline
\end{tabular}

( $n=52)$ most frequently indicated shopping for apparel 1-2 times $(n=35)$ each year.

\section{Part II}

\section{Perceptions of fashion}

Younger female consumers (age 18-21, $\mu=19.5, n=33$ ) and older ones (age 70-85, $n=8$ ) rated the fashion of 18 illustrations of diverse women's trouser ensembles, resulting in a mean perception of fashion of 2.12 ( $\mathrm{SD}=0.12)$ from the older female consumers and a mean perception of fashion of $1.82(\mathrm{SD}=0.22)$ from the younger ones. This difference was statistically significant (independent sample $t$-test, $P<0.01$ ), indicating that younger and older women have different ideas about what is fashionable in women's wear. In general, the older consumers rated the trouser ensembles as being more fashionable than did the younger ones.

\section{Discussion}

The majority of the respondents in this study were widowed, but enjoyed annual incomes above $\$ 20000$. Their cognitive ages were on average 19.24 years younger than their chronological ages (among those whose cognitive ages were lower than their ages, $n=30$ of 34), supporting the results of previous studies concerning cognitive-chronological age variations in the mature market. Also congruent with previous investigations was the fact that subjects who evidenced lower cognitive ages also tended to be the most fashion conscious (i.e. more interested in and receptive to the change and newness that characterizes any fashion system).

The concepts of fashion and fashion imply group acceptance, adoption and/or admiration of a prevailing style. However, the results of this study suggest that a one-style-fits-all definition of fashion may be somewhat off-target in regards to ideas about fashion held by older consumers. In this study, there were significant differences in perceptions of fashion between older and younger market segments toward given trouser ensembles, with university students evidencing more negative perceptions concerning fashion of the research stimuli. As the size of the mature market continues to expand during the upcoming decades, such divergent definitions of fashion will have an inevitable impact upon the marketplace.

Schiffman and Sherman (1991) observed that members of the so-called new elderly market segment are 'selectively innovative', or receptive to product innovations if those innovations provide identifiable consumer benefits. Perceptions of benefits, of course, are value driven. Previous research concerning consumer values from an age-based perspective has suggested that valuing of comfort or ease increases with age (Lu and Shih, 1997). In this study, preferences for fit and comfort were somewhat more valued than fashionable. Thus, older women's greater perceptions of fashionable trousers (than that evidenced by younger consumers) might represent a 'selective' or comfort-benefit definition of fashion.

The results of this study supported probable links between cognitive age and fashion consciousness, paralleling previous research results. Fashion-conscious mature consumers tended to have younger cognitive ages (even though their chronological ages were slightly higher), while lower fashion-conscious respondents 
had higher cognitive ages (although slightly younger chronologically). In other words, identifying those consumers who have a positive predisposition toward fashion products will require collection and analysis of psychographic (not just demographic) data.

\section{Recommendations}

During test administration, the challenges of surveying respondents in their 90s and older quickly became evident. Some subjects were frustrated and stymied by questions that requested ranking or Likert-type responses, resulting in lower Ns for some portions of the instrument. Therefore, when developing methodologies for future investigation of older market segments, it is recommended that serious consideration be given to personal one-on-one formats.

The results of this study suggested that a majority of mature women are moderately to very interested in clothing, the changing trends in apparel styles, and their own appearance (i.e. they are fashion conscious). However, businesspersons desiring customers from this lucrative market must recognize that although mature women value 'dressing smartly', they do not do so at the expense of comfort. In other words, attracting apparel purchases from older women will necessitate integrating elements of current fashion with comfort factors, such as: (1) good fit with adequate ease; (2) soft, non-abrasive materials; (3) adequate insulation or ventilation (depending upon the season); and (4) garment lengths and fullness that facilitate free, uninhibited movements. Also, the dual preferences for trousers (rather than dresses) and stylishness that were evidenced by the mature women in this study suggest that apparel businesses would be well advised to diversify trouser offerings beyond the T-shirt and polyester pant outfits often stereotypically associated with older women. For example, offering fashionable suits in both skirted and trouser versions would enable mature women, as well as younger consumers, the enjoyment of participating in fashion-forward trends.

For many of the women in this study, fashion was a discussion topic of at least moderate interest and popularity during social interaction with peers. The pleasurable aspects of fashion were further suggested by the fact that approximately half of the subjects stated that they purchased new apparel for personal enjoyment. Apparel businesses would be wise to capitalize on this predisposition by associating pleasurable value-added experiential benefits with the clothing selection and purchasing process: fashion shows, fashion consultations, fashion clubs, fashion tours, etc.

Szmigin and Carrigan (2001) observed that 'If the old always stay the same, then maybe there is no need for further research' (p. 31). In reality, the senior market consists of continuous, sequential waves of age cohorts, as those cohorts progress into their older years. Age cohorts, or groups of persons born during the same period and therefore influenced by the same environmental events, are believed to develop cohort-unique values, attitudes and beliefs (Schewe and Noble, 2000). Therefore, the results of any study of the mature market are valid only in so long as the sampled age cohort remains in place. As new cohorts enter the mature segment, the characteristics of that segment will change.

As increasing numbers of ageing baby boomers advance further into their older years, the segment characteristics revealed by this study may well be altered. For example, boomers have had greater experience with computer technology. Therefore, with their inclu- sion in the older market segment, preferred means of acquiring fashion products or fashion information may shift from bricksand-mortar formats to electronic ones, in contrast with the trend evidenced by the results of this investigation. Continuous resampling and reassessment of the older population will be essential to maintain an understanding of the heterogenous and changing characteristics of this important age group.

\section{References}

Anonymous. (2004) Older is better: senior market trends. Growth Strategies, 964, 2-4.

Barak, B. (1987) Cognitive age: a new multidimensional approach to measuring age identity. International Journal of Aging and Human Development, 25, 109-125.

Barak, B. \& Gould, S. (1985) Alternative age measures: a research agenda. In Advances in Consumer Research, Vol. 12 (ed. by E. Hirschman \& M. Holbrook), pp. 53-58. Association for Consumer Research, Ann Arbor, MI.

Barak, B. \& Schiffman, L.G. (1981) Cognitive age: a nonchronological age variable. In Advances in Consumer Research, Vol. 8 (ed. by B. Kent \& A. Monroe), pp. 602-606. Association for Consumer Research, Ann Arbor, MI.

Barak, B. \& Stern, B. (1985) Fantastic at forty! The new young woman consumer. Journal of Consumer Marketing, 2, 41-54.

Carrigan, M. (1998) Segmenting the grey market: the case for fifty-plus lifegroups. Journal of Marketing Practice, 4, 43-56.

Carrigan, M. \& Szmigin, I. (1999) In pursuit of youth: what's wrong with the older market? Marketing Intelligence and Planning, 17, 222-231.

Chowdhary, U. (1988) Self-esteem age identification, and media exposure of the elderly and their relationship to fashion. Clothing and Textiles Research Journal, 7, 23-30.

Corlett, C. (1998) Shattering the stereotypes of the 50+ shopper: marketing. Vital Speeches of the Day, 64, 478-480.

Gardyn, R. (2002) Oh, the good life. American Demographics, 24, 31-35.

Greco, A.J. (1986) The fashion-conscious elderly: a viable, but neglected market segment. The Journal of Consumer Marketing, 3, 71-75.

Greco, A.J. \& Paksoy, C.H. (1989) Profiling the mature fashion-conscious apparel shopper. Akron Business and Economic Review, 20, 7-23.

Jonathan, G. \& Mills, M.K. (1982) Fashion life cycle, self-concept, shopping orientation, and store patronage: an integrative analysis. Journal of Retailing, 58, 64-87.

Kaiser, S.B. \& Chandler, J.L. (1984) Fashion alienation: older adults and the mass media. International Journal of Aging and Human Development, 19, 203-221.

Kaiser, S.B. \& Chandler, J.L. (1985) Older consumers' use of media for fashion information. Journal of Broadcasting and Electronic Media, 29, 201-207.

Lee, R. (1997) The youth bias in advertising. American Demographics, 19, $46-50$.

Long, N. (1998) Broken down by age and sex: exploring the ways we approach the elderly consumer. Journal of the Market Research Society, 40, 73-91.

Lu, L. \& Shih, J. (1997) Sources of happiness: a qualitative approach. Journal of Social Psychology, 137, 181-187.

Lumpkin, J.R. (1985) Shopping segmentation of the elderly consumer. Journal of Academy of Marketing Science, 13, 68-69.

Lumpkin, J.R. \& Darden, W.R. (1982) Relating television preference viewing to shopping orientation. Lifestyles, and Demographics, Journal of Advertising, 11, 56-57.

Mathur, A., Sherman, E. \& Schiffman, L. (1998) Opportunities for marketing travel services to new-age elderly. Journal of Services Marketing, 12, 265-277. 
Miller, C. (1993) Image of seniors improves in ads. Marketing News, 27(25), 8-11.

Richards, E.A. \& Sturman, S.S. (1977) Life style segmentation in apparel marketing. Journal of Marketing, 41, 89-91.

Ross, S. (2000) Senior webizens. Brandweek, 41, 46.

Schewe, C. \& Noble, S. (2000) Market segmentation by cohorts: the value and validity of cohorts in America and abroad. Journal of Marketing Management, 16, 129-142.

Schiffman, L. \& Kanuk, L. (1994) Consumer Behavior. Prentice Hall, Englewood Cliffs, NJ.

Schiffman, L. \& Sherman, E. (1991) Value orientations of new-age elderly: the coming of an ageless market. Journal of Business Research, 22 , 187-194.

Sherman, E., Schiffman, L.G. \& Dillon, W.R. (1988) Age/gender segments and quality of life difference. In 1988 Winter Educator's Conference Proceedings (ed. by S. Shapiro et al.), pp. 319-320. American Marketing Association, Chicago, IL.

Silvers, C. (1997) Smashing old stereotypes of 50-plus America. Journal of Consumer Marketing, 14, 303-309.
Solomon, M. \& Rabolt, N. (2004) Consumer Behavior in Fashion. Prentice Hall, Englewood Cliffs, NJ.

Stephens, N. (1991) Cognitive age: a useful concept for advertising? Journal of Advertising, 20, 37-49.

Summers, J.O. (1970) The identity of women's clothing fashion opinion leaders. Journal of Marketing Research, 7, 178-185.

Szmigin, I. \& Carrigan, M. (2001) Learning to love the older consumer. Journal of Consumer Behavior, 1, 22-34.

Thomas, V. \& Wolfe, D.B. (1995) Why won't television grow up? American Demographics, 17, 24-27.

Tunaley, J., Walsh, S. \& Nicolson, P. (1999) I'm not bad for my age: the meaning of body size and eating in the lives of older women. Ageing and Society, 19, 741-759.

Walsh, G., Mitchell, V.W. \& Thuran, T.H. (2001) German consumer decision-making styles. The Journal of Consumer Affairs, 35, 73-96.

Wilkes, R.E. (1992) A structural modeling approach to the measurement and meaning of cognitive age. Journal of Consumer Research, 19, 292301. 